\title{
The grey zone: the ordinary violence of extraordinary times
}

\author{
Srila Roy, University of Nottingham
}

Published in the Journal of the Royal Anthropological Institute, 14:2, June 2008 (author's copy)

The article analyses the 'ordinary' violence of revolutionary politics, particularly acts of gendered and sexual violence that tend to be neglected in the face of the 'extraordinariness' of political terror. Focusing on the extreme left Naxalbari movement of West Bengal, it points to those morally ambiguous 'grey zones' that confound the rigid distinctions between victim and victimizer in insurrectionary politics. Public and private recollections of sexual and gender-based injuries by women activists point to the complex intermeshing of different forms of violence (everyday, political, structural, symbolic) across 'safe' and 'unsafe' spaces, 'public' and 'private' worlds, and communities of trust and those of betrayal. In making sense of these memories and their largely secret or 'untellable' nature, the article places sexual violence on a continuum of multiple and interrelated forces that are both overt and symbolic, and include a society's ways of mourning some forms of violence and silencing others. The idea of a continuum explores the 'grayness' of violence as the very object of anthropological enquiry.

The line between the revolutionary and the fascist has always been drawn sharply in the revolutionary political imaginary. Foucault's (1984) question - how does one keep from being a fascist, even and especially when one believes oneself to be a revolutionary militant? - has largely gone unanswered. Indeed, Foucault's scepticism about the revolutionary subject could not ring truer at a time when the costs of insurrectionary political cultures are rapidly becoming evident in the context of mounting militarism in south Asia. In the face of human rights violations, internal killings and sexual violence, the ethical distinctions between the victim and the victimizer, the hero and the aggressor, have become less discernable. ${ }^{i}$ The lived space of revolutionary politics has come to constitute a zone of indiscernibility - a Levian grey zone in which the network of human relations can no longer be reduced to two blocs of victims and persecutors (Levi 1998). ${ }^{\text {ii }}$ The late 1960s Naxalbari andolan of West Bengal constitutes one such 'morally ambiguous space' of complicity and betrayal (Scheper-Hughes \& Bourgois 2004:10). Focusing on the underground life of the movement, this article draws attention to some of the 
more secret, silent, and salient 'costs' of revolutionary politics, particularly to everyday acts of sexual and gender-based violence. It is written in the spirit of a contribution to a gender-based critique of the revolutionary left (and militant politics more generally) but also as an invitation to a more serious reflection on the 'everydayness' of sexual violence in the context of, and continuous with, other forms of (political) violence. Beyond militant politics, such an investigation has direct implications on our ability (obligation?) to recognize the 'grey zones of violence which are, by definition, not obvious' (Scheper-Hughes \& Bourgois 2004:22).

\section{'Extraordinary' and 'everyday' violence}

The 'extraordinariness' of the violence of 'Naxalbari' is still legendary. The very origin of the movement can be traced to the violent repression of a peasant uprising in 1967 in the village of Naxalbari (in northern West Bengal) - a singular episode that has come to occupy an iconic position in the history of Indian communism and democratic struggles more generally. It was this originating myth of Naxalbari that propelled India's third communist party, the Communist Party of India (Marxist-Leninist), into existence. Armed with a copy of Mao's Red Book, middle-class youths and students left homes to 'integrate' with the peasantry and become guerillas in an armed struggle against the state. The political line of khatam or the individual annihilation of 'class enemies', first instigated against landowners in rural areas, escalated into what has often been referred to as an orgy of violence. Small guerrilla units, primarily of men, killed traffic policemen and local schoolteachers in the city of Kolkata, which by then emerged as the unlikely centre of revolutionary action. The state retaliated with a brutal offensive that marked the most violent period in the history of postcolonial West Bengal. 
The 'excesses' of violence - of the state and that of the revolutionary - have not been ignored in historical or popular memory. A privileging of the extreme nature of political terror has amounted, however, to a neglect of the more 'ordinary' forms of violence that underlie revolutionary political cultures like the CPML. ${ }^{\text {iii }}$ Within the community of activists, the construct of the repressive state often exhausts the potential for recognizing violence elsewhere, such as in the politics of everyday life and within the textures of interpersonal relationships. So while the figure of the raped woman is exemplary of the ravages of state terror, the gendered vulnerability that structured the underground life of the movement has scarcely been included in historical understandings of Naxalbari violence (e.g. Ray 1980; Banerjee 1980). Indeed, such forms of violence, often perceived as a threat to internal political solidarity, are subject to practices of willful forgetting.

The identification of violence with its most extreme manifestations is not limited to the historiography of the radical left. Within the feminist scholarship on insurrectionary politics in south Asia (Saldhana 1986; Custers 1987; Kannabiran \& Lalitha 1989; Stree1989; Vindhya 2000; Kannabiran \& Kannabiran 2002), political violence has been fairly narrowly defined as statesponsored terror, besides being located outside the social and the everyday. While little has been said about sexual harassment at the hands of male Party comrades, feminists have critiqued left political practices for instituting techniques of discipline and punishment in the name of upholding group morality, the objects of which are invariably women. Members of the Stree Shakti Sanghatana, writing about women in the Telangana struggle, root the constraints placed upon female sexuality and the threat of sexual harassment in the Party's inability to let go of 'the traditional assumption that prevailed in feudal society that woman was the bearer of virtue and tradition [...]' (1989:268). In reducing the Party morality to a traditional 'feudal' one, this 
feminist critique returns, paradoxically, to the same leftist position that it has been at pains to deconstruct: that women's oppression is mainly feudal. How can such a critique explain those forms of violence that are not straightforwardly locatable in patriarchal, feudal ideologies? And what of the new forms of gendered violence that radical politics institute, often embedded in fantasies of heroism and a utopian future and, equally, in liberatory ideals of class, gender, and sexuality? To a large extent, sexual violence remains, in much of this literature, the dark underside of progressive politics, its perverted form rather than a product of violent political cultures (see, however, Bhatia 2006). The question of women's empowerment in relation to radical left-wing politics has also been debated in separation from that of violence (Omvedt 1993).

What provides a productive resource in this context are recent anthropologies of violence (e.g. Jeganathan 2000; Das et al. 2000; Kleinman 2000; Scheper-Hughes \& Bourgois 2004; Bourgois 2001; Banerjee et al. 2004; Coronil \& Skurski 2006) that have broadened the concept of political violence, enriched conceptions of social suffering and everyday violence, and the relationship between violence and subjectivity. Veena Das's (2007) research on the Indian Partition is exemplary of the turn, both ethnographic and analytic, toward an identification of violence in its daily, invisible or 'banal' forms - what Nancy Scheper-Hughes (1992) calls 'the violence of everyday life' (see also Kleinman 2000) - away from the impulse to exceptionalize violence. Das shows how the violence of extreme events such as Partition comes to be incorporated in the temporal structure of relationships and within the weave of daily life. In her ethnography, one gets a concrete sense of the relation between the eventful and the ordinary: between large-scale events of political turmoil and the legacy of everyday lifeworlds that are the site of betrayal and violation but also that of recovery and hope. 
The anthropological turn towards the everyday and the ordinary with respect to violence has not, however, always been committed to mapping how such violence is continuous with (but not reducible to) all other violence. For continuity is not simply a heuristic device in the study of violence but part of its ontological structure. Here I am thinking of Philippe Bourgois's ethnography of post-war El Salvador, which explores how structural and political violence translate into symbolic and everyday forms. His is one of the few ethnographies that challenges the liberal romanticisation of guerrilla warfare, demonstrating how political repression and resistance against it transform into forms of symbolic and everyday aggression such as internal killings and gender oppression. Yet it is not enough to read this ethnography as a critique of revolutionary movements alone. Drawing on Bourdieu's sociology of multiple and interrelated fields, Bourgois posits an understanding of violence that goes beyond addressing its everyday expressions to its complex location within broader political, structural and symbolic processes and their underlying gendered logic. He treats violence as a continuum of overlapping forms and forces, be they political, structural or everyday and especially symbolic. Bourdieu (2001; see also Bourdieu \& Wacquant 1992) uses the concept of symbolic violence to designate a 'gentle violence' that operates with the complicity of the oppressed or what he calls misrecognition such that structures of inequality and oppression appear natural. Such symbolic violence (of which gender oppression is paradigmatic) is the lynchpin for perpetuating unequal power relations in 'normal' times. Together with Scheper-Hughes, Bourgois (2004) proposes a violence continuum that shapes the contours of everyday life as well as the more visible expressions of genocide. ${ }^{\text {iv }}$ Again, they turn to Bourdieu to conceptualize the intimate links between normative forms of everyday violence and the genocidal violence of 'abnormal' times, striving to 'trouble' these categorical distinctions within the study of violence. The concept of a continuum is especially 
productive for an analysis of situations of conflict in which 'spectacular' political violence tends to deflect 'unspectacular' forms, contributing to the social invisibility and normalization of the latter.

Following the lead of such anthropologies and countering the mainstream mystification of Naxalite violence, this article turns to the everyday as a starting point from which to understand the manner in which the trauma of Naxalbari was lived and subjectively experienced. I locate sexual violence on a continuum that maps the interrelationship between distinct forms of violence, the ways in which they conjugate and shade into one another such that the boundaries between forms of violence become more fluid. The idea of a continuum captures not only the varied idioms of male sexual aggression within the movement but also relates, as we shall see, acts of injury at the micro and interpersonal level to an originary political violence. In mapping the complex continuities between different forms and expressions of violence, the article explores violence as an object of anthropological enquiry.

\section{The ethnographic context}

Quotidian forms of violence assumed particular force, as testimony and silence, in my interviews with middle-class women activists. The material forming the basis of this article came from indepth, qualitative interviews with mainly female activists in Kolkata (conducted between 20032004). A majority of my interviewees can be identified as lower middle-class or nimno moddhobitto, several of them refugees from the Bengal Partition. ${ }^{\mathrm{v}}$ Most of the women are today salaried professionals or full-time political activists, married with grown children. They also form part of a fairly recognisable clique of 'Naxalite women', partly ascribable to their prolonged incarceration in Kolkata, but mostly to their present-day status as political activists, writers or 
intellectuals. Some have emerged as prominent figures within the women's movement (and the political-intellectual life of the city more generally) through their association with autonomous or leftists women's groups. I also met women who lie relatively outside this clique such as Supriya and Ajita who are cited in this article. ${ }^{\mathrm{vi}}$ Both women continue to have strong political commitments even though they have moved away from mainstream politics and activism. While my respondents have varied feelings about their past involvement in radical left politics (ranging from regret to an active ideological commitment), a common investment in feminist politics ${ }^{\text {vii }}$ is a major point of camaraderie among them, many of whom never knew each other at the time of the movement.

Some of these women have contributed to the growth of a small but significant body of women's writing on revolutionary life, especially its gender/sexual politics. These include novels, poetry, memoirs (including two well-known prison memoirs by Joya Mitra and Minakhi Sen), and essays published in various non-mainstream 'little magazines' in Bengali. Supriya and Krishna's short memoirs published in these journals (Bandyopadhyay 2001 and Sanyal 2001) were central to an initial identification of the manner in which women experienced the violence of the time in their daily lifeworlds - as fear for their bodily integrity, as a betrayal of trust, as trauma. The gendered and sexual violence that these texts speak of does not have the self-evident or taken-for-granted quality that the violence of the state assumes. ${ }^{\text {viii }}$ The impetus of the text is, rather, to uncover, in a retroactive feminist mode, those forms of violence that were, at the time of the movement, not easily identifiable or nameable as such. The writing of this article moves between the experiences recounted in these published memoirs and private recollections of sexual injury obtained through formal interviews with women - spoken less in a testimonial mode than as hidden conversations or even as a 'public secret' (Taussig 1999). 


\section{Narrating violence}

I did not enter the field expecting to hear stories of sexual abuse (including rape), domestic violence, failed marriages and unhappy relationships. The threat of sexual abuse in Supriya and Krishna's published memoirs reoriented my expectations to a certain extent but still left me unprepared to grapple with the traumatic nature of these memories. Past experiences of (sexual) injury were not articulated in a testimonial mode or as public performances, and yet (as Das notes of her own work with Partition survivors) they lingered on the edges of conversations. These memories were of the nature of something secret, silenced or hidden away; in need of narrative uncovering and public validation. They seemed to disturb the otherwise seamless manner in which past events associated with Naxalbari have been assimilated into the present. The disruptive nature of these memories and the power of their revelation were only made evident through a change in tone, the dipping of voice, or even the complex repertoires of denying and domesticating sexual violence (see Roy 2007). Women's insistence on anonymity hinted further at the powerful hold of a past that had become a burden in the present.

What ultimately enabled a narration of intimate experiences of aggression and betrayal within the highly constrained space of the interview was the establishment of a 'narrative contract' (Kaviraj 1992) between the speaker and her audience, based on their common appeal to the language of feminism. The Indian women's movement has affected significant semantic shifts particularly in the discourse of violence against women. Its influence on the 'tellability' of testimonies of sexual wrongs in the public sphere cannot be underestimated. Whether interviewees explicitly aligned themselves with feminist politics or not (and several did), the recognition that it provides to their speech rendered those stories 'sayable' that might have been unspeakable in other contexts. Thus 
Ajita and my common appeal to feminist discourses enabled her to 'come out' with a story of an abusive relationship while she was in the andolan. The fact that Ajita abruptly stopped speaking of her first marriage when her adult children entered the room, resuming her story only when the door had been safely shut, implies that what she disclosed to me could not be readily articulated elsewhere. Other women punctuated their testimonies with the disclaimer 'what I'm telling you now I haven't told anyone else', indicative of the difficulty of drawing on a culturally available but still marginalized story of surviving sexual violence.

The power of a narrative like feminism is, therefore, relative. Some of the testimonies of sexual violence that I examine in this article (such as Supriya and Ajita's) continue to be voiced in the context of a normative silence. This is demonstrated by the emphatic need of both women to remain anonymous. While the need for anonymity can be attributed to the demands of class, family and respectability, or even to concerns of privacy and intimacy, it is also attributable to the hegemonic force of leftist discourse. Krishna, one of the few women to have publicly condemned male sexual violence, has, for instance, been accused (by her own comrades) of trying to 'destroy' the movement. Perceived as a threat to an imagined political community, such stories are discouraged from open articulation even though they are commonly known and discussed in private. They function in a manner that is similar to the 'public secret' in Michael Taussig's (1999) sense as that which is generally known but cannot be publicly articulated. It is to the complexities of these memories that we now turn.

\section{Zones of safety and zones of danger}

While only a few middle-class women participated in the political campaign in the countryside (see Bandyopadhyay 2001), they did go 'underground', living a clandestine life with industrial 
workers and urban slum-dwellers. Apart from a small number of anti-colonial 'terrorist' women, this was the first time that married and unmarried middle-class women entirely left the domestic space and the family to freely move across the rural/urban landscape, assume alternative identities, and lead entirely new lifestyles. Still, the division of political labour within the CPML echoed that of the anticolonial terrorist tradition in which women were, by and large, considered as auxiliaries to male revolutionaries.

While in the city or village, activists were provided shelter by peasants, labourers, or by middleclass households who were either sympathizers or families of political activists themselves. Outside the 'battle zone', the shelter was conceived of as a place of sanctuary, trust and renewal. The shelter occupies a crucial position in a continuum of violence, made all the more complex by its peculiar positioning within the public-private divide. As the bari was politicized in its transformation into a shelter, its privacy was compromised. At the same time, as a household, it functioned as a domestic space. It could thus claim privacy and autonomy on behalf of its members, the family. It was also this metaphor of the family that constituted the shelter as a private 'nonpolitical' space, protected from encroachments from the outside world. The shelter thus emerged as a zone of safety, especially for women whose very entry into the political domain often hinged on the availability of shelters. In women's narratives, by contrast, it is this space that emerges in its dailiness as a site of vulnerability and terror.

The construal of the shelter (and the 'underground') as a zone of safety was also aided by the perception of what lay 'outside' its borders as dominated by the state and consequently as a site of danger. As the custodian of all forms of violence, the construct of the state exhausted the potential for recognizing violence and terror in Naxalbari discourse. The threat posed by the state 
thus obliterated the possibility of violence existing outside its boundaries, transforming the movement's space into an inherently secure zone of mutual trust. The state is also masculinised in Naxalite discourse, and women are invariably defined in terms of their 'rapability' (Marcus 1992) at the hands of the state. Some women suggested that the threat of rape at the hands of the police made leaving the Party an impossibility. The construct of a rapist state not only aided the creation of an illusion of safety but also placed structural limitations on women's mobility. It magnified the violence that existed 'out there', in the public domain, while rendering invisible the violence that existed within the movement, at the hands of one's own community. Paradoxically, as I go on to show, the originary violence of the state and that of 'class oppression' was also what rendered visible acts of wounding within the movement.

\section{Sheltering violence}

Women were often 'sheltered' in all-male households or left alone with male members. The threat of assault was implicit in the homes of relative strangers, and also in those of known political sympathizers. In her published memoir, Supriya details three incidents in which she faced sexual threats by very different categories of aggressors within the confines of the political shelter. The first incident took place in the industrial belt in which she was living and conducting political work:

The terror that chases women the most is the fear of being raped. That experience happened to me here for the first time. One evening, a slightly inebriated Gobardhan tried to use force on me. He was, in our thinking, the potentially most advanced worker in that area. I quickly recovered from my shock and resisted. He left with his head lowered. Later he came and begged me to keep the matter a secret. I refused. I read out some leader's quotations to him from a book to show him how one can correct ones mistakes, how one can cultivate self-criticism (Sanyal 2001:17). ${ }^{\text {ix }}$ 
Supriya notes, not without some irony, how the Party considered her sexual aggressor to be the 'most advanced worker' in that area. Her testimony is the occasion for a powerful overturning of the movement's cherished icon - the male subaltern. It also bears witness to some of the strategic forms of resistance and self-protection that women had developed at the time. Supriya, for instance, attempts to rehabilitate her aggressor (through political consciousness-raising) by making him realise his 'mistake'. The discursive construction of sexual violence as a 'mistake' mirrors its popular conception as individual weakness, completely divorced from any structural conditions to do with (gendered) relations of power. Supriya's rehabilitative attempt also resonates with the Naxalbari discourse of self-transformation (or becoming 'de-classed' ${ }^{\mathrm{x}}$ ) through the acquisition of political (and ethical) consciousness. Women's disciplinary regimes of safety and managing risk were thus filtered through such 'official' discourses.

If rape was at an extreme end of the sexual violence continuum, there were other less clearly definable forms of male intrusion that could only be resisted through silences and withdrawals. The second incident that Supriya recounts was in the middle-class home of a male comrade. While trying to sleep, Supriya found her male comrade's father (whom she called meshomoshai, or uncle) touching her. What Supriya can today identify and name as a sexual threat was not so easily accomplished at that time. The location of violence within the 'safe' space of the household together with the subjective location of her aggressor - a respected older male member of a middle class household (as opposed to a working class comrade who could be politically 'rehabilitated') - made naming let alone testifying less than straightforward. Supriya is quick to point out that strategies of resistance were severely limited in the exceptional circumstances of her life in the context of an armed struggle. She writes how she could not talk about these incidents or tell anyone: 
Along the way I realised that I would feel nowhere more secure than at home. It is mainly one's own responsibility. But I won't deny the fact that in general, I received sympathetic behaviour from other comrades and sisters and aunts. But maintaining secrecy had become such a habit that all things could not be told to everyone (2001:17).

The inability to tell 'all things ... to everyone' (see also Bandyopadhyay 2001) overdetermined a female silence in relation to sexual aggression. There are two aspects to this silencing that can briefly be noted. First is the relationship between secrecy and silence. Participation in an outlawed political movement that was entirely 'underground' meant that the need to maintain secrecy was incumbent upon all its participants, especially as state terror heightened and 'informers' infiltrated the ranks of the movement. The ability to act autonomously in the political domain entailed such public secrecy, understood in Taussig's terms as 'knowing what not to know' (1999:2). Like their male comrades, women were expected to perform this labour of secrecy as an obligation for political agency, but the obligation also came to include an active silencing of private injury. This is hardly surprising given that a silencing of the private and the personal has long been part of what it means to be a communist. The fetishization of secrecy in the name of 'class struggle' thus became expressed as a silencing and suppression of routine acts of injury at the micro and interpersonal level.

While the nature of silencing can be located in a continuum of political and everyday violence (and the demands of political agency), it must also be understood in terms of normative codes of gender, class, and sexuality that demand female silencing of sexual wrongs in the name of honour or respectability. The hegemonic nature of such codes made it difficult to implicate meshomoshai in a discourse of sexual aggression, just as it transformed, as we see below, resistance to male force into 'consent' in marriage. Marriage (see Roy 2006) was the clearest means of ensuring 
respectability for women activists, besides being a way of protecting oneself from unwanted sexual advances. As with marriage, 'silencing' can be seen as a mode of retrieving respectability or even as a strategy of self-protection, especially when we consider the Party's invalidation of female speech in testimony.

\section{Communities of trust and trauma}

The psychological costs of actively repressing the threat of abuse were high for women. Supriya was repeatedly 'taken advantage of' by a leader (a married man with children) at various shelters in which she, this man, and another male comrade lived. Supriya had left the Party with a man whom she calls 'comrade S' and her close confidant, Arun. ${ }^{\mathrm{xi}}$ They were her 'guardians', her only refuge from a hostile world. As her 'guardian', this man cared for her as a 'mother' while exploiting the symbolic paradigm of motherhood in everyday acts of violation.

What used to happen was that the whole day I would sit in the room, my head would ache and he would press my head, just like $m a$, just like $m a$ - press my head, my legs and in doing this, it would become more. At some point, I thought that this is not correct, it's becoming too much. ${ }^{\text {iii }}$

Comrade ' $\mathrm{S}$ ' is positioned in her narrative as a nurturing figure. But somewhere this image of him becomes less stable. His acts of touching her, initially understood as caring, began to sexualise her. Women's testimonies of incest often express ambivalence and confusion when touch is no longer affectionate but seems just wrong. It is still hard to cast male protectors (fathers, brothers, 'guardians') in the role of sexual aggressors. Supriya's words powerfully resonate with these testimonies when she says that she developed a 'weakness' towards this man who cared for her - 'I couldn't dismiss him right away as being bad, that was my weakness'. In the grey zone of the shelter, knowing your enemy from your friend was not always straightforward, especially for women. This ambiguity rendered the closest of relationships 
precarious, not entirely free from the possibility of betrayal. Male sexual power was achieved, in turn, through an exploitation of this very structure of fear and vulnerability in which women were located. 'S' persuaded Supriya that while she was asleep, her trusted friend, Arun, had actually touched her. In this manner, ' $\mathrm{S}$ ' ensured Supriya's silencing of sexual abuse by poisoning her relationship with Arun.

If sexual violence silenced women's speech, it was the body that responded and resisted:

I saw him at about 14/15 shelters. Once the people of the house had left he came and tightly held me, but when people came, he would let me go. Now this behaviour of his is it correct or incorrect?; this would trouble me, that he didn't do this in front of others. Then I felt that there was something different in this, otherwise he would do it in front of everyone. Then I started to feel bad. I would become very 'stiff'... I kept thinking that he shouldn't think that I'm responding to him. [...] They were my 'guardians', where would I go? And the others at the PUC, they were worse; you couldn't trust them at all... I couldn't even tell Arun, how could I tell the others?

In becoming 'stiff', Supriya's objectified body ensured a minimal degree of resistance to male dominance. Resistance could, however, be expressed only at this level of embodiment given the minimal resources and bargaining power that women had at their disposal. 'Where would I go?' Supriya asks, making the operation of violence within private and public worlds an intimate one. The inability to leave, the compulsion to be silent, the normative spaces of 'inside' (the shelter) and 'outside' (the PUC), and finally the allusion of trust ('they were my guardians') and its betrayal ('you couldn't trust them at all') - all contributed to the temporary psychological breakdown that Supriya says she suffered at the time. Her experience of betrayal at the hands of trusted 'guardians' who were meant to protect her was a traumatic one, more so than the routinised forms of aggression that she faced from unknown male workers or sympathizers, the risk of which could (at least to a certain degree) be strategically managed. One way to think of these latter episodes is in Das's (2007:7) terms as interrupting the ordinary but still as a part of 
the everyday. What rendered the experience with ' $S$ ' traumatic was perhaps a 'failure of the grammar of the ordinary'- an inability to discern those who care for us from those who wish to harm us. Supriya's psychological breakdown emerged from the fact that those who were meant to afford her protection turned against her. For someone who was never arrested at the time of the movement, the violence of Naxalbari lay not so much in the brutality of the state but in the conflation of intimacy and betrayal that took place within communities of care and protection. The 'extraordinary' violence of the time folded, in this manner, into the everyday structure of interpersonal relationships (Das 2000).

\section{The continuum between sexual violence and marriage}

The embeddedness of abuse in intimate relationships was also enabled by the progressive redefinition of marriage within the movement (Roy 2006). Marriage was redefined in terms of companionate marriage based on love and comradeship in contradistinction to arranged marriages, the most common form of matrimony in middle-class Bengali society. Yet marriage, even in its transformed and liberatory sense, often left (both middle-class and tribal) women vulnerable to sexual harassment by male comrades.

Ajita, who came from a relatively affluent family, speaks of the manner in which she was 'forced' to marry a unit leader:

A relation developed and that relation, when I realised that it wasn't right, then, it became almost like a question of pressurising... one boy forcefully wanted me... wanted me for a long time. He was a leader. He would organize the shelters in such a way that he would get me. I knew him as our unit leader but that was all. He fixed where I would stay [which unit/shelter]... then I fell into such a situation where, and my thinking was also that if a boy stays with a girl at the same place, then... that she would get a bad reputation. My thinking was wrong. 
What Ajita's narrative makes clear is that the hierarchical organization of political labour within the movement in which women activists were subordinate to male leaders was an enabling factor for sexual exploitation. This together with the division of space afforded male leaders the privilege to pursue and exploit women cadres, as in this case, where a male leader effectively controlled a female cadre's mobility. What can also be noted is the fusion of ideals of free choice and middle-class norms of sexual morality that (re)produced female vulnerability in particular ways. In Ajita's case, a relationship had developed but more importantly an 'impression' had been created. It was the burden of this 'impression' that made marriage incumbent on her, even when a relationship of choice became one of force. The Party, she says, 'took it for granted and didn't try to understand the condition. I wasn't in a situation where I could speak to anyone'. While romantic relationships flourished in the movement, the possibility of coercion and force was not recognized within them. The Party's regulatory stand on sexuality also meant that relationships could not but end in marriage. In Ajita's case, the pressure to conform to middle class norms of sexual respectability together with the threat of sexual shaming transformed 'force' into 'consent' to marriage (Das 1996).

What is also significant in Ajita's story is the continuous evocation of self-blame and selfrefutation that determines her relationship to a traumatic past. Although Ajita does blame the Party - '[...] a lot of girls' lives have been ruined because of the mishandling of the Party. Some are able to come out of it, some aren't and they have to suffer through their lives' - she blames herself far more for being weak, and for not being able to resist male dominance. As with Supriya, the memory of betrayal by a familiar (once loved) other is narrativized through guilt and self-blame, paradigmatic of what Bourdieu (2001) calls the symbolic violence of masculine domination whereby victims not only fail to recognize the oppressive power relations within 
which they are implicated but actually blame themselves for its effects. This symbolic violence is further naturalised in a political rhetoric in which structural limitations of patriarchy (and class) are decisively transformed and attributed as female weakness or wrongness.

A blurring of the boundaries between sexual violence and marriage was not exclusive to middle class women. Let me turn to a male narrative that draws attention to a hitherto unrecognized aspect of sexual violence - the sexual exploitation of adivasi (tribal) women by middle-class revolutionaries, and that too, under the sign of 'marriage'. Saumen's discussion of sexual violence is one of the few I encountered from male activists. He suggests that bhadralok comrades often 'married' adivasi women as testament to their truly integrated and 'de-classed' nature:

The boys who came from Presidency College (I won't give you any names but what I'm telling you is 'authentic') - many good, well-known Presidency College boys with 'good results', who went to Gopiballavpur, their 'method of integration' was to stay at peasant homes as man and wife. And under the influence of some famous Naxalite leaders, young, unmarried girls got 'pregnant' there, peasant girls. I can bring you a witness who has 'helped' one such girl. They would go and as man and wife, would be with this girl and that girl [...] then at another place, they would also be husband-wife. [...] This incident, this 'reckless' behaviour that I can do anything and that it is 'justified' in the name of revolution [...].

It seems that sexual relations with adivasi women formed the cornerstone of the ritual of becoming 'de-classed'. Subaltern female sexuality functions, in this instance, as a metonym for a superior, truly de-classed revolutionary masculinity. Saumen goes further to suggest that the promise of 'revolution' ultimately provided a secure, legitimising framework for such acts of symbolic violence given that they remained couched within the fantasy of a class-based societal transformation. The violation of peasant women by Party activists, like that of middle-class 
women by subaltern men, constitutes the final grey zone in which the line between the protector and aggressor becomes exceedingly hard to draw.

\section{$\underline{\text { The 'official' adjudication of rape }}$}

Women's testimonies of sexual violence at the time of the movement were, I have suggested, structured through the necessity and active cultivation of silence. When women did testify to sexual abuse, their testimonies were often received with disbelief, disqualified or simply ignored by Party members. Women needed certain qualifications to be recognized as fully legitimate victims of sexual violence. ${ }^{\text {xii }}$ Class was a central qualifying attribute but not an unequivocal one. So while the rape of peasant women by landlords or repressive state forces was politically acknowledged as a form of class oppression, that of middle-class women at the hands of lowerclass/caste men was routinely denied. Sexual violence was cognized and mediated through an axiological understanding of 'class' and 'class oppression', and as a reflection of (and response to) the originary political violence that the revolutionaries were organising against. To this extent, the violence within the quotidian life of the movement was rendered visible and made continuous with the violence that existed 'outside' - the violence of class struggle.

Joya, a prominent ex-activist, narrated an incident to me that became fairly representative of the Party's negotiation with sexual violence faced by middle-class women. A woman activist had repeatedly complained to the Party about the intentions of a newly recruited male comrade towards her. Party members dismissed her anxieties by blaming her 'middle-class mentality'. Her accusations were, in fact, falsified on the basis of the class differentials that existed between victim and victimiser. She was told, according to Joya: 
You're an officer's daughter and just because he's a worker and he's dark-looking you're accusing him.

Eventually the woman was raped. The man apparently confessed his crime to the Party but blamed the 'old madhyabitta vices' that still existed in him. The Party let him off. Amongst my interviewees, Minakhi and Krishna have similar stories to tell. Both women just about escaped being assaulted while carrying out Party work. The Party, however, chose to disbelieve the women owing to the working-class status of their sexual aggressors. Constituted by the Party as a disembodied deified icon, the male subaltern could not be recognized as a subject implicated in a discourse of sexual violence. Instead, it is the injured female subject who emerges not only as a lying subject but also as a victimiser who (like the state/ruling class) oppresses the male subaltern on class lines. Rape itself is mediated through a reified logic of 'class oppression' (premised on the naturalisation of 'class') suggesting a reduction of sexual violence at the micro level to the violence of class struggle that the movement was engaged in, in the public domain. It is the public domain that emerges, in Party logic, as the sole site of violence conflating the experience of wounding within the movement to that outside of it, and ultimately re-inscribing the publicprivate dichotomy.

Acts of injury within the movement are, in fact, repeatedly located outside its boundaries. I am thinking here of the first incident in which the man confesses his crime but reduces his act of rape to a madhyabitta 'vice'. His deployment of such a defence is not surprising given that the Party imbued social categories (such as class) with moral worth. The act of rape came to be articulated axiologically - as a vice that was located outside the male subaltern body in an external agent. While in legal discourse men are said to act out their 'natural sexual instinct' when they rape women (Das 1996), here they fall prey to class-based vices. In the former, rape is normalised 
through its naturalisation in male desire/sexuality; in radical left discourse, its naturalisation operates through the category of class. The reduction of rape to reified constructs of class not only diminishes its gendered and sexualised nature but also minimises the need to act against instances of abuse since these are construed as something the community has inherited from an external agent. The community itself is purged of all evil which is projected onto larger madhyabitta society. As with the construct of the rapist state, we see how the possibility of violence within the community is disavowed through a series of oppositions with an imagined other, here constructed as 'madhyabitta vices'.

Let me end this section by briefly noting the manner in which Party ideologues did condemn and convict male offenders, and the politics of retribution in these instances. These show that even within the core of silence and denial cultivated in the movement, there was a thread of recognition with respect to violence against women. Krishna illustrates an incident in which a woman activist complained to the Party leadership about a middle-class comrade's inappropriate behaviour towards her:

A meeting was called to prosecute the male comrade. Almost all the members of the leadership and few of us women gathered at a house for the meeting. Several discussions followed. It was decided at the meeting that the women would make the final decision. The woman who had suffered the harassment began. Shaking with rage and hatred, she uttered only one thing: 'The only punishment for this crime is khatam'. The other women got very excited; one by one they all uttered the same word, 'khatam'. I began to feel rather nervous about putting forth my own view. Although I knew that my sole refutation would not stop the 'khatam', I still had to voice it. [...] [She tells the gathering] 'No man has the right to disrespect any woman. If a male comrade has behaved inappropriately towards a woman comrade then he must be severely punished. But why khatam? We have all become intoxicated with the idea of khatam. [...] Then we will have to kill some others present here' [She asks the other men present there] 'Can all of you honestly say that you have never behaved inappropriately towards your women comrades?' [...] I had said this as representative of all the women comrades since I knew that many of them had faced similar experiences (Bandyopadhyay 2001:97-98). 
Within the qualified space instituted by the Party (the 'trial'), it became ideologically consistent to punish/kill middle-class men as plausible perpetrators of sexual violence. The avenging of sexual harassment with 'annihilation' is a frightening instance of the replication of the 'extraordinary' violence that the movement was organising against within its own structures and internal relations, such that violence became 'a banal instrumental necessity' (Bourgois 2001:11) ${ }^{\text {xiv }}$ Within the habitus of the movement, the taking of life was not viewed as an excess but simply as the natural order of things. The commonsense normalization of political violence at the time of Naxalbari thus deemed khatam as the only justice for sexual harassment.

The incident narrated by Krishna is not an isolated one. Molina Dhak, the only woman in West Bengal to be given a life-sentence, murdered her rapist, a middle-class political sympathizer who had given her shelter. An article on Molina published in The Telegraph describes the Party's support for her action:

Malina reported the incident to the Party which took great exception: firstly, a woman was humiliated; and secondly, members saw the act as a deliberate threat to their work and safety of the activists (Dasgupta 1998).

As before, the Party recognized acts of abuse committed by its own middle-class cadres and sympathizers even though it normalised the exercise of sexual violence by subaltern men. The class distinction is significant - it suggests a redistribution of class capital within radical left politics. Unlike in juridical discourse, it is men of upper caste/middle-class groups and not of the lower classes who are constructed as plausible perpetrators of crimes against women in ways that are consistent with the wider ideological motivations of the left. Once again, khatam becomes the only viable way in which the Party can respond to rape. The act of sexualised wounding is also presented through the language of humiliation (that is gendered female; see Basu \& Roy 
2007:23) and as a threat to the security of all Party members. Sexual violence is no longer an act that simply 'humiliates' women but affects the 'physical safety of all bodies' (Menon 2004:137).

While there were certain qualified spaces within the movement in which violence against women was afforded a degree of recognition, these were also, it can be argued, spaces of misrecognition. By making examples of a few middle-class male perpetrators, the Party could relinquish its own responsibility towards its members and install a safety valve for a repressive community. Such a safety valve did little to alter (or even recognize) the structural determinants of patriarchy, class or caste within (and outside) the movement. These were perceived as natural within the habitus of the movement. The sanctioning of khatam as a form of retributive justice carried out by (or on behalf of) the wounded female subject was also seen as the natural order of things. However, the Party sanctioned female militancy only when there was a confluence of individual interests with those of the larger community. By contrast, women's naming of violence as violence towards women was rendered unsayable and disqualified.

The Party's response to sexual offences against women was neither straightforward nor consistent. The category of sexual violence and that of the perpetrator and victim were not stable categories. They were varyingly constructed within the discursive field of gender and class relations in the movement. Some forms of sexual violence (such as the rape of peasant women by the state) were more easily incorporable into a reified discourse of class oppression. Others that defied such easy incorporation were suppressed and misrecognized. As with legal constructions in 'normal' times, rape was varyingly constructed as a metonym for class oppression or as an offence against the community as a whole. It was rarely recognized as an offence against the 
bodily integrity of all women. These constructions of rape enabled, in turn, the discursive (im)possibility of women's testimony, and normalised the exercise of male sexual violence. ${ }^{\mathrm{xv}}$

\section{Concluding reflections}

In narratives of revolutionary resistance against state power, the battle lines are drawn all too starkly with the righteous violence of the revolutionary falling on one side and the illegitimate force of the state on the other. This need, which Levi (1998) notes, to be able to take sides for the sake of moral clarity is not limited to revolutionary discourse but also permeates historical writing and the memorialisation of militant struggles. How does one recollect experiences of betrayal and violation suffered at the hands of one's comrades and not at those of the enemy within such a landscape of memory? Such memories are often experienced as a burden or as risky insofar as they constitute a zone of ambiguity where the division between the protector and the persecutor begins to blur.

The narratives we have here encountered speak of this ambiguity under whose sign revolutionary relations were lived at the time of the movement (Levi 1998). For women activists, spaces of safety were often those of danger, and the community of trust to which one belonged lost its taken-for-granted quality. In their strategies of self-protection (including secrecy and silencing), women's narratives present a structure of vulnerability and betrayal that was revealed by everyday life in the movement. Everyday life itself becomes other than the site of the ordinary upon which trust can be unhesitatingly placed (Das \& Kleinman 2000:8). Rigid divisions and taxonomies of violence are equally hard to sustain within this grey zone once we consider the manner in which the extremity of political violence reverberated in the dynamics of everyday interpersonal relationships. I have found an understanding of violence as a continuum a 
meaningful way to explore an enmeshing of the violence that was 'external' and 'internal' to the revolutionary community, and the production of subjectivity at this point of suture. The trauma of 'class struggle', especially that of state repression, left invisible the structures of power and vulnerability that constituted daily underground life. At the same time, it was this originary violence that rendered visible the experience of sexual violence within the movement insofar as acts of rape were cognised through the logic of 'class' and 'class oppression' or even as 'middle class vice'. Such an axiological understanding of violence masked (and thereby normalised) the complex idioms through which male power operated in context-specific ways - through a deification of the male subaltern, through generational difference and respect for older men, through friendship and intimacy, and through the disqualification of women's speech. The Party played a crucial role in creating the conditions for rape to occur with impunity by treating rape as mimetic of the 'public' violence that the revolutionaries were organising against, to be avenged through the sanctioning of khatam. A final theme of the grey zone here emerges in the manner in which the revolution can end up using the very same power it attempts to overthrow.

If we treat violence as a continuum, we might come to a better understanding of sexual violence as an object of anthropological enquiry, especially in the context of revolutionary struggles where it operates both overtly and symbolically, making it hard to recognize and challenge. For one, the violence continuum opens up an analytic space for appreciating, in concrete terms, the multiple forms and intensities of gendered violence, beginning with obviously violent acts like rape and shading into actions that do not seem violent at all, such as gestures or forms of intimate intrusion or the practice of marriage. Bourdieu's theorisation of symbolic violence is especially significant here in drawing attention to those invisible modes of gendered domination that not only underlie daily rituals of sleeping and being 'sheltered' but also larger orders of power that are scarcely 
recognized as such. The fact that forms of violence are not neatly separable from (and mutually implicate) one another does not render the category of sexual violence indefinable or empty. Rather it allows us to recognize the grayness of gendered violence and the violences of everyday life more generally.

But the 'violence continuum' does not simply contribute to an expansion of normative conceptions of violence, a key objective of the feminist engagement with (and critique of) the radical left. It makes it impossible to separate (as some feminists have inadvertently enabled) the question of gender/sexual politics from the logic of insurrectionary struggle by linking patriarchal and class-based ideologies to those of righteous, revolutionary violence. Whilst not reducible to any of these ideological forces, violence against women in the context of the Naxalite movement was fuelled by the coalescence of political, structural and symbolic violence that rendered, via misrecognition, even more natural an unequal gender order.

My usage of a violence continuum has not only mapped the gendered links between different forms of violence (political, everyday, symbolic) but has also sought to understand a society's response to particular forms of violence, its ways of mourning some forms of wounding and silencing others. Even as women like Supriya and Ajita bore witness to the injuries embedded in their pasts, they did so under the sign of a coercive silencing, exemplified in their need to remain anonymous. These stories are still untellable in the wider public domain and remain as hidden and secret memories, in spite of the recognition that feminist politics provide for them. This article's discussion of the tellability and untellability of some forms of violence should make clear that not all events or experiences come under the sign of violence; and what is violence and what is not is, as Jeganathan (2000:64) notes, constituted and ultimately made available to 
anthropology by politics. I take Jeganathan's claim not to mean that politics interrupts or limits the work of anthropology but that it creates a space that can embrace the politics of those objects under investigation. I hope this essay has shown that it is the grayness of violence that ultimately makes violence intelligible to anthropology. 
Acknowledgements: This article develops from my research on the cultural memory of the Naxalbari movement in West Bengal, made possible by the generous support of an Overseas Research Student Award, a University of Warwick Postgraduate Research Fellowship, and a Feminist Review Trust Writing Up Scholarship. I thank Deborah Lynn Steinberg, Parita Mukta, Rafael Winkler, the four anonymous reviewers and editors at JRAI for their engagement with my work. This research would not have been possible without the support of the women and men interviewed in Kolkata. 


\section{Bibliography}

Bandopadhyay, K. (2001) ‘Abirata Larai’ [Relentless Struggle], Khonj Ekhon, No I., May

Bandyopadhyay, R. (2000) Journal Shottor, Kolkata: Mitra \& Ghosh

Banerjee, S. (1984) India's simmering revolution: the Naxalite uprising, London: Zed

Banerjee, S. et al. (2004) 'Engendering Violence: Boundaries, Histories, and the Everyday', Cultural Dynamics, 16(2/3): 125-139

Basu, A. \& S. Roy (eds.) (2007) Violence and Democracy in India, Calcutta: Seagull Books

Baxi, P. (2005) The Social and Juridical Framework of Rape in India: Case Studies in Gujarat, Unpublished Ph.D. Thesis: Delhi School of Economics, University of Delhi.

Bhatia, B. (2006) 'On Armed Resistance', Economic and Political Weekly, 22 July, 3179-83

Bourdieu, P. (2001) Masculine domination, tr. Richard Nice, Cambridge: Polity

Bourdieu, P. and L. J.D. Wacquant (1992) An invitation to reflexive sociology, Cambridge:

Polity Press

Bourgois, P. (2001) 'The Power of Violence in War and Peace: Post-Cold War Lessons from El Salvador', Ethnography, 2 (1): 5-34.

--- (2002) 'The violence of moral binaries: Response to Leigh Binford', Ethnography, 3(2): 221231

Coronil, F. \& J. Skurski (eds.) (2006) States of Violence, University of Michigan Press

Custers, P. (1987) Women in the Tebhaga Uprising: rural poor women and revolutionary leadership (1946-47), Calcutta: Naya Prokash

Das, V. (1996) 'Sexual Violence, Discursive Formations and the State', Economic and Political Weekly, Special Number, September, 2411-2423

--- (2000) 'Violence, Knowledge and Subjectivity' in Veena Das et al. (eds.) Violence and Subjectivity, New Delhi: Oxford University Press

--- (2007) Life and Worlds: Violence and the Descent into the Ordinary, Berkley: University of California Press

Das, V. \& A. Kleinman (2000) 'Introduction' in V. Das et al. (eds.) Violence and Subjectivity, New Delhi: Oxford University Press 
Dasgupta, R. (1998) 'Freedom', The Telegraph, March 29

Dasgupta, R. (2003) Marxism and the Middle Class Intelligentsia: Culture and Politics in Bengal 1920s-1950s, Unpublished D.Phil Thesis: Oxford University

Featherstone, M. (1992) 'The Heroic Life and Everyday Life', Theory, Culture \& Society, 9(1): $159-82$

Foucault, M. (1984) 'Preface' in G. Deleuze and F. Guattari, Anti-Oedipus: capitalism and schizophrenia, tr. R. Hurley, M. Seem, and H. R. Lane, London: Athlone

Jeganathan, P. (2000) 'A space for violence' in P. Chatterjee \& P. Jeganathan (eds.) Community, Gender and Violence, Subaltern Studies XI, New Delhi: Permanent Black

Kannabiran, K. (2002) 'A Ravished Justice: Half a Century of Judicial Discourse on Rape' in K. Kannabiran \& V. Kannabiran, De-Eroticising Assault: Essays on Modesty, Honour and Power, Kolkata: Stree

Kannabiran, K. \& V. Kannabiran (2002) De-Eroticising Assault: Essays on Modesty, Honour and Power, Kolkata: Stree

Kannabiran, V. \& K. Lalitha (1989) 'That Magic Time: Women in the Telengana People's Struggle' in K. Sangari \& S. Vaid (eds.) Recasting Women: Essays in Colonial History, Delhi: Kali

Kaviraj, S. (1992) 'The Imaginary Institution of India' in Partha Chatterjee and Gyanendra Pandey, (eds.) Subaltern Studies VII, New Delhi: Oxford University Press

Kelly, L. (1988) Surviving sexual violence, Cambridge: Polity

Kleinman, A. (2001) 'The violences of everyday life: the multiple forms and dynamics of social violence' in V. Das et al. (eds.) Violence and Subjectivity, New Delhi: Oxford University Press

Levi, P. (1998) The drowned and the saved, transl. by R. Rosenthal, London: Joseph

Marcus, S. (1992) 'Fighting Bodies, Fighting Words: A Theory and Politics of Rape Prevention' in J. Butler \& J. W. Scott (eds.) Feminists theorise the political, New York; London: Routledge

Menon, N. (2004) Recovering Subversion: Feminist Politics Beyond the Law, Delhi: Permanent Black

Moser, C. (2001) 'Gendered Continuum of Violence and Conflict: An Operational Framework' in C. Moser \& F. Clark (eds.) Victims, perpetrators or actors?: gender, armed conflict and political violence, London; New York: Zed Books

Omvedt, Gail (1993) Reinventing Revolution: New Social Movements and the Socialist Tradition in India, New York and London: M.E. Sharpe 
Ray, R. (1988) The Naxalites and their ideology, Delhi; Oxford: Oxford University Press

Ray, R. (1999) Fields of Protest: Women's Movements in India, New Delhi: Kali for Women.

Roy, S. (2006) 'Revolutionary marriage: on the politics of sexual stories in Naxalbari', Feminist Review, 83 (1): 99-118

--- (2007) Remembering Revolution: gender, violence and the production of identity in Naxalbari, unpublished Phd Thesis: University of Warwick

Saldhana, I. (1986) 'Tribal Women in the Warli Revolt: 1945-47: 'class' and 'gender' in the Left perspective', Economic and Political Weekly, XXI, 17: WS 41-WS 52

Sanders, M. (2001) 'Afterword: Extraordinary violence’, interventions, 3 (2): 242-250

Sanyal, S. (2001) Biplaber Sondhane ek Sadharon Meye [An ordinary girl in search of revolution], Monthon Patrika, November-December

Scheper-Hughes, N. \& P. Bourgois (2004) 'Introduction: Making sense of Violence' in N. Scheper-Hughes \& P. Bourgois (eds.) Violence in war and peace: an anthology, Malden, MA: Blackwell Publishers

Stree Shakti Sanghatana (1989) 'We were making history...': life stories of women in the Telangana People's Struggle, London: Zed

Taussig, M (1999) Defacement: public secrecy and the labor of the negative, Stanford: University Press

U. Vindhya (2000) 'Comrades-in-Arms: sexuality and identity in the contemporary revolutionary movement in Andhra Pradesh and the legacy of Chalam' in M. E. John \& J.Nair (eds.) A question of silence? The sexual economies of modern India, London: Zed 
${ }^{\mathrm{i}}$ The recent Maoist attack in the state of Chhattisgarh in northern India in which more than 40 adivasis were killed/ injured is a case in point here.

ii Primo Levi's (1998) 'grey zone' captures the central ideology of the Nazi concentration camps where victims, victimizers and witnesses found themselves in a web of complicity to the extent that it became impossible to attribute moral responsibility to a clearly defined group of 'perpetrators' alone. The Sonderkommando Jews (responsible for maintaining the gas chambers) are the clearest instance of the Nazi strategy of placing the burden of guilt on victims themselves. My usage of the term in the very different context of radical politics counters the moral absoluteness in which the revolutionary and the state are usually placed. Instead, I signal a blurring of moral boundaries between the revolutionary and the state, and the inadequacies of 'binary conceptions of worthiness' (Bourgois 2002:228) to understand the politics of revolutionary struggles.

iii By 'extraordinary' I refer to those forms of violence that are rendered publicly visible and externally acknowledged (by the state and civil society agents such as the media) as being extreme and traumatic. Violence of this kind has generally been theorized in academic terms as being sudden and episodic, as a disruption of the ordinary and the everyday (Jeganathan 2000). In human rights jargon, the generation of violence as 'extraordinary' is entailed in its declaration as a 'gross violation' of human rights (Sanders 2001). By contrast, 'ordinary' forms of violence are marked by their lack of public recognition and are quasi-synonymous with that which remains invisible, silent, intimate, structural or even unconscious. The 'ordinary' also contains an element of the banal and the routine- terms that denote the structure of everyday life (Featherstone 1992). In the context of Naxalbari, the political violence of the state and that of the CPML has emerged as the more glaring forms of violence in contrast to certain others that remain buried in this history.

${ }^{\text {iv }}$ Scheper-Hughes and Bourgois' usage of a violence continuum demonstrates the rearticulated relevance of a concept that has been axiomatic in feminist activism and theorisations of violence against women in the 'second wave' (see, for instance, Kelly 1988). See also Moser (2001) on a gendered continuum of violent conflict.

${ }^{\mathrm{v}}$ The Bengali middle-class (madhyabitta), comprising of an upper-caste Hindu landed elite and a petty bourgeois, originally located itself below the aristocracy and above the labouring classes and the lower castes in the nineteenth century. The bhadralok madhyabitta has come to signify a heterogeneous middle-class in Bengal with culture and education as its primary social capital. The Naxalbari movement had a largely lower middle-class character, dominated by a vernacular intelligentsia that was antagonistic towards the upwardly mobile 'sahebi' or English speaking elite (Ray 1988).

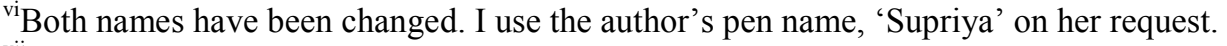

${ }^{v i i}$ By 'feminist' I refer here to the ideals and values of the women's movement in India. 'Feminism' itself remains a highly contested term in India given its continued association with 'western feminism'. On the autonomous women's movement in Kolkata, see Ray 1999.

viii Sexual and gender-based violence refers to the range of abuses and threats that women faced within the political field. These included acts of physical assault, rape, acts that stopped short of rape, unwanted gestures, sexually inflected and sexist comments, and domestic abuse.

${ }^{i x}$ All translations from the original Bengali texts are my own.

${ }^{x}$ The idea of 'declassing' the self in order to revoke the ideological distance between the 'intellectual' and the masses has a long-standing tradition in middle-class Bengali Marxist politics. See Dasgupta 2003.

${ }^{x i}$ Both are pseudonyms used by Supriya in her published memoir.

${ }^{x i i}$ The interviews were conducted in Bengali. Words that appear in single quotation were originally spoken in English.

xiii The Party's response to sexual violence parallels the judicial discourse on rape in India within which only certain kinds of (moral/modest/undesirable) women can be plausible victims of rape as opposed to others (see Das 1996; Kannabiran 2002; Baxi 2005). The continuum that the Party's discourse forms with judicial discourses in 'normal' times shows the extent to which emancipatory politics are implicated in the very power structures that they seek to overcome.

${ }^{\text {xiv }}$ Internal killings within the CPML are another instance of this mimetic process. I was told of two prominent cases where dissenters within the Party were 'annihilated'.

${ }^{x v}$ My discussion in this section has been greatly aided by Pratiksha Baxi's (2005) research on the manner in which the rape law in India normalizes rape and disqualifies women's testimony to sexual violence. 